\title{
The Effect of Website Design Quality, E-Service Quality, and Brand Image on E-Satisfaction and E- Loyalty of E-Commerce Customers
}

\author{
Tesa Daniati, Rr. Ratna Roostika \\ Department of Business and Economics, Universitas Islam Indonesia
}

\begin{abstract}
This study aims to analyze the variables that affect the satisfaction and loyalty of e-commerce customers. This study uses a structural equation model (SEM) analysis. The data used in this study is secondary data collected using a questionnaire from e-commerce customers in western Indonesia as many as 300 respondents. The results found that Website Design Quality and E-service Quality positively and significantly affect Esatisfaction. Brand Image positively and significantly affects ELoyalty. Then E-satisfaction positively and significantly affects E-Loyalty.
\end{abstract}

Keywords: SEM, Satisfaction, Loyalty, E-commerce

\section{INTRODUCTION}

A ccording to statistics, nearly 4.57 billion people were active internet users as of July 2020, this represents 59 per cent of the world's population. According to Internet World Stats, Indonesia's internet users in 2000 were 2,000,000 people with a population of $211,540,429$, then increased significantly in 2020 as many as $171,260,000$ people with a population of $273,523,615$. It shows that internet growth in $2000-2020$ is $85.60 \%$. Indonesia is the 4 th largest internet user in the world. The rapid development of information technology has an impact on several sectors such as social, political and economic. This condition encourages business people to sell online, otherwise known as e-commerce.

According to Wong (2010), e-commerce includes buying, selling and marketing goods and services through electronic commerce. According to Wear Social and Hootsuite, around $90 \%$ of internet users in Indonesia have shopped online. Meanwhile, according to data from the Indonesian Ministry of Communication and Information Technology in 2019, the growth of e-commerce in Indonesia reached $78 \%$ and was the highest in the world. This phenomenon has triggered the birth of many online transaction platforms. The data for the second quarter of 2020 shows that Shopee's monthly visitor numbers are 93.4 million, Tokopedia with 86.1 million, Bukalapak with 35.2 million, Lazada with 22 million and Blibli with 18.3 million. In this study, the author limits the scope of the research to only that e-commerce based on the influence of website design quality, brand image, e-service quality toward consumer satisfaction and loyalty.

According to Flavian et al (2009), the quality of the design does not only show a good appearance but also the level of ease of use of a product. Design quality can affect the affective perception of the user. Based on the ExpectationConfirmation Theory (Oliver, 1977; Oliver, 1980), when the perceived quality of website design exceeds consumer expectations, they will feel satisfied.

E-service quality can also affect customer satisfaction and loyalty. According to Zeithaml et al (2005), e-service quality shows the extent to which a website can facilitate consumer activities efficiently and effectively, such as shopping, purchasing, and others. Research by Prasetyo et al (2018) on 100 Lazada consumers showed that e-service quality had a positive effect on e-satisfaction. Meanwhile, Perwira et al (2016) found that e-service quality had a significant effect on the satisfaction and loyalty of 115 Tokopedia consumers.

In addition to the preceding two variables, brand image is also an important factor in customer satisfaction and loyalty. According to Kotler (2002), brand image is a consumer's perception of both the image of the company and the products. Pramudyo (2012) explains that image has a significant role and can affect consumer perceptions and expectations about the products and services offered so that it can affect consumer satisfaction. Furthermore, Pramudyo (2012) found a positive influence of brand image on customer loyalty.

However, the research by Yeridha et al (2019) found that brand image did not affect GO-JEK customer loyalty. In addition, research by Romadhan et al (2019) also found that eservice quality did not affect the loyalty of Lazada consumers. Therefore, we are interested to research this topic with the title the effect of website design quality, e-service quality and brand image on e-satisfaction and e-loyalty of e-commerce customers.

\section{THEORETICAL REVIEW}

\subsection{Theoretical Background}

According to Sutabri (2012), E-commerce is the distribution, purchase, sale, marketing of goods and services through electronic systems such as the internet or television, websites, or other computer networks. Meanwhile, according to Jony (2010), e-commerce (electronic commerce) is the buying, selling and marketing of goods and services through 
electronic commerce. In the context of e-commerce, customer satisfaction and loyalty are important factors that must be a concern for an e-commerce company.

\section{Consumer Loyalty}

Loyalty is defined as a repeat purchase behaviour and is driven by a favourable attitude towards the subject including aspects of attitude and behaviour. True loyalty shows higher purchase intention (Shankar et al., 2003). According to Srinivasan, et al. (2002), e-loyalty is defined as a customer's positive attitude towards e-retailers which results in repeat purchase behaviour. Oliver (1997) defines loyalty as a customer's commitment to making repeated purchases at the same company.

The change to online consumption has made researchers develop the concept of loyalty into e-loyalty. Anderson and Srinivasan (2003) define e-loyalty as the perceived benefits of consumers from online sites that encourage repeat purchase behaviour.

\section{E-Satisfaction}

E-satisfaction is defined as customer satisfaction related to previous purchase experiences in e-commerce (Anderson and Srinivasan, 2003). According to Oliver (1997), satisfaction is defined as pleasurable fulfilment. Meaning that consumers feel that the fulfilment of consumption of a need, desire, goal, and so on makes consumers feel happy.

Satisfaction can be interpreted as an expression of whether consumers like it or not that compares expectations and reality to a product and service obtained (Kotler and Keller, 2007).

\section{Website Design Quality}

According to Flavian et al (2009), the quality of the design does not only show a good appearance but also the level of ease of use of a product. Design quality can affect the affective perception of the user. Based on the ExpectationConfirmation Theory (Oliver, 1977; Oliver, 1980), when the perceived quality of website design exceeds consumer expectations, they will feel satisfied. Thus, website design quality can be defined as the quality of the website as measured by all aspects such as appearance, navigational ease, language used and the suitability of the page with customer preferences.

According to Yuhefizar (2013), the website is the entire web page of a domain. The quality of a web design can be determined by the quality of the navigation system and website appearance (McKnight et al. 2002; Cyr et al. 2008; Zhou et al. 2009; Wilson and Keni 2018; Bernarto et al. 2019).

\section{E-Service Quality}

Parasuraman and Maholtra (2005) define e-service quality as the extent to which the website can facilitate efficient and effective consumer activities such as shopping, purchasing, and others. According to Zeithaml et al (2005), e-service quality shows the extent to which a website can facilitate consumer activities efficiently and effectively, such as shopping, purchasing, and others. Research by Prasetyo et al (2018) on 100 Lazada consumers showed that e-service quality had a positive effect on e-satisfaction. Meanwhile, Perwira et al (2016) found that e-service quality had a significant effect on the satisfaction and loyalty of 115 Tokopedia consumers.

Customer ratings of website quality and e-service quality include their experience when interacting with the site and post-service satisfaction. Core service quality includes efficiency, fulfilment, system availability, privacy. Meanwhile, e-recovery service quality includes responsiveness, compensation, contacts and others (Parasuraman \& Grewal, 2000).

\section{Brand Image}

A brand is a name, term, sign, symbol, design, or a combination of these that indicates the identity of a seller's products and services that differentiates his products from those of competitors (Kotler \& Armstrong, 2008). Furthermore, Kotler (2002) defines brand image as a consumer's perception of the image of the company itself and the products produced by the company. Meanwhile, According to Setiadi (2003), brand image is defined as a representation of the overall consumer perception of the brand which is formed from information and consumer experiences of the product.

Image has a significant role in influencing consumer perceptions and expectations about the products and services offered by the company so that it can affect consumer satisfaction (Pramudyo, 2012).

\subsection{Previous Study and Hypothesis}

\section{Website design quality on e-satisfaction}

Research conducted by Lin (2010) found that the quality of website design has a positive effect on customer satisfaction. The better the website design quality, the more impact it has on increasing customer satisfaction (Bernarto et al., 2019). The Expectation-Confirmation Theory (Oliver, 1977; Oliver, 1980) explained that when the perceived quality of website design exceeds consumer expectations, they will feel satisfied. Many empirical studies have found a significant effect of website design quality on satisfaction (McKinney \& Yoon, 2002; Shim et al., 2002; Cheung \& Lee, 2005; Wixom $\&$ Todd, 2005). Therefore, we formulate a hypothesis:

H1: Website design quality has a positive effect on Esatisfaction of e-commerce customers.

\section{E-service quality on e-satisfaction}

Tobagus' research (2018) found that e-service quality has a positive and significant effect on the e-satisfaction of Tokopedia customers. E-service quality is positively related to 
e-satisfaction. Increasing e-service quality will have an impact on increasing e-satisfaction.

According to research by Permana et al (2018), there is a significant influence between each dimension of electronic service quality such as efficiency, system availability, fulfilment, privacy, responsiveness, compensation, and contact and Shopee customer satisfaction in Bandung. Hence, we formulate the following hypothesis:

H2: E-service quality has a positive effect on E-satisfaction of E-commerce customers

\section{Brand image of e-satisfaction}

According to Pramudyo (2012), the image has a significant role in influencing consumer perceptions and expectations about goods or services. Thus, an image of a product can affect consumer satisfaction. According to Pramudyo (2012), the brand image has a significant role in influencing consumer perceptions and expectations about the goods or services offered by the company which then affects consumer satisfaction.

Research by Malik, et al (2012) found that brand image has a positive and significant effect on customer satisfaction. Hatane and Julian (2019) also found the influence of brand image on customer satisfaction. The better the image of a brand, the higher the level of satisfaction felt by consumers. Hence, we formulate the following hypothesis:

H3: Brand image has a positive effect on e-satisfaction of ecommerce customers

\section{Website design quality on e-loyalty}

Customer satisfaction is an important factor that has the most influence on customer loyalty (Kanning and Bergmann, 2009; Amin., 2010). Research by Puspitasari (2013) found that website quality has a significant effect on customer loyalty. Website quality affects the perceived value of customers. These results are in line with Fahmi (2018) who found that website quality has a positive and significant effect on loyalty where website quality has a positive effect on online shop customer loyalty in Medan City. Hence, we formulate the hypothesis:

H4: Website design quality has a positive effect on e-loyalty of e-commerce customers

\section{E-service quality on e-loyalty}

Laurent (2016) found that e-service quality has a positive effect on customer loyalty. It means that the e-service quality provided by the company is good enough, so that loyalty is formed. Meanwhile, Perwira et al (2016) also found that eservice quality had a significant effect on loyalty.

Meanwhile, Ramadhan et al (2019) found that e-service quality did not have a significant effect on the loyalty variable in the Lazada application. Hence, we formulate the hypothesis
H5: E-service Quality has a positive effect on e-loyalty of ecommerce customers.

\section{Brand image on e-loyalty}

Research by Pramudyo (2012) found that there is a significant influence of brand image on loyalty. These results indicate that consumers become loyal due to the positive brand image of the company.

On the other hand, Yeridha et al (2019) found that brand image had no significant effect on customer loyalty for GOJEK online motorcycle taxi services in Samarinda. Hence, we formulate the hypothesis:

H6: Brand image has a positive influence on e-loyalty of ecommerce customers

\section{E-satisfaction on e-loyalty}

Research by Santika and Satria (2018) found that esatisfaction has a positive and significant effect on the eloyalty of tourists using online travel sites in Bali. Lin and Sun (2009) said that customer e-satisfaction can directly and positively affect customer e-loyalty.

Akhter et al. (2011) found that customer loyalty is directly and positively influenced by customer satisfaction. These results are in line with research by Lin and Sun (2009) which found that customer e-satisfaction can directly and positively affect customer e-loyalty.

Santika and Satria (2018) found that e-satisfaction has a positive and significant effect on the e-loyalty of tourists using Bali travel online sites. Therefore, the more customer satisfaction increases, the more loyalty increases. Meanwhile, customers who are not satisfied with the products and services purchased will tend to switch to other brands and will leave that brand (Anderson and Srinivasan, 2003). Hence, we formulate the hypothesis:

H7: E-satisfaction has a positive effect on e-loyalty of ecommerce customers.

Meanwhile, the research model that will be used can be seen in the figure below:

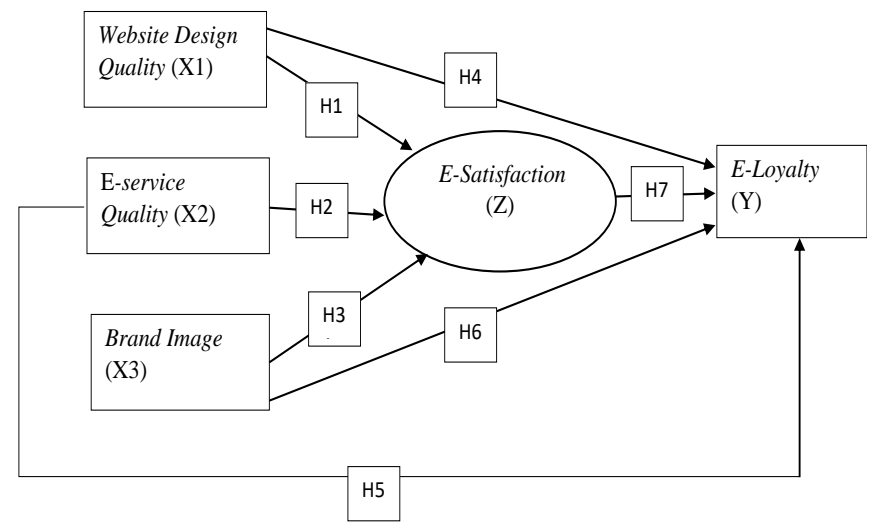

Figure 1. Research Model 


\section{METHODOLOGY}

This research was conducted in Sumatra and Java. The population is Indonesian e-commerce consumers and customers. The sample of this research is consumers and ecommerce customers who use Shopee, Tokopedia, Bukalapak, Lazada, JD.id, Blibli and other e-commerce companies. The number of samples is determined with a maximum $(33+5) \mathrm{x}$ $10=380$ and a minimum $(33+5) \times 5=190$. For this study, a sample of 300 respondents was taken.

The sample in this study was taken with a nonprobability sampling approach. Distributed by convenience sampling method to those who can be found on social media and willing to give answers as respondents. Data was collected through a questionnaire using Google Form. This study uses a Likert scale with five scales, namely Strongly Agree (SS), Agree (S), Disagree (KS), Disagree (TS), Strongly Disagree (STS). follow:

While the indicators used to measure each variable are as

Table 1. Measurement Variable

Website Design Quality (Dianne et., al 2008; Nazirah \& Utami, 2017)

1. The menu is neatly and arranged

2. Product information can be found easily

3. Website looks more professional with good design.

4. Product information is displayed consistently and sensibly.

5. The appearance of the website (colours, boxes, menus, navigation tools, etc.) looks good and is displayed well

6. Websites are easy to browse

7. Grouping, ordering, and overall arrangement are understandable and easy to use

8. All product options, product attributes, and product information are well designed and displayed

9. Product availability and product diversity are well explained

E-Service Quality (Zeithaml et al. 2009)

1. Efficiency

2. Fulfilment

3. System availability

4. Privacy

5. Responsiveness

6. Compensation

7. Contact Canter

Brand Image (Wulandari et al., 2018)

1. Quality of products

2. Produced by a trusted company

3. Brands are easy to get

4. A strong brand in the minds of consumers

5. A trustworthy brand

6. Brands are easy to identify

7. Brands provide more benefits

E-Satisfaction (Ranjbarian et al., 2012; Prayitno, 2015)

1. Satisfied with the quality of service

2. Recommend products/services to others

3. the desire not to switch to another product/service

4. Proud to use the service/product

5. Satisfied with the final product/service received

E-Loyalty (Anderson dan Srinivan, 2003)

1. Consumers don't want to switch to other online sites

2. Consumers try to use this online site when making a purchase

3. When consumers want to place an order, this online site is the first choice
4. Consumers feel happy to use this online site

5. For consumers, this online site is the best

6. Consumers believe that this site is the consumer's favourite online site

The analytical method used to test the hypothesis is the Structural Equation Model (SEM). The analytical procedures carried out are: first, data evaluation consisting of sample size, normality and outliers. Second, testing the suitability of the model against various goodness of fit criteria, namely X2 Chi-Square of $\mathrm{p}>0.05$ or $\mathrm{p}>0.10, \mathrm{CMIN} / \mathrm{DF} \mathrm{CMIN} / \mathrm{DF}$ where the value is good if it has a value $<2.0$ and finally GFI, AGFI, TLI, CFI where the value is good if it has a value > 0.90 .

The results of the AMOS calculation will be taken to test whether the hypothesis can be accepted or not. The hypothesis can be accepted if the p-value is less than 0.05 (5\%).

\section{RESULT AND DISCUSSION}

\subsection{Statistical Result}

Structural modelling is done by connecting latent constructs, both endogenous and exogenous.

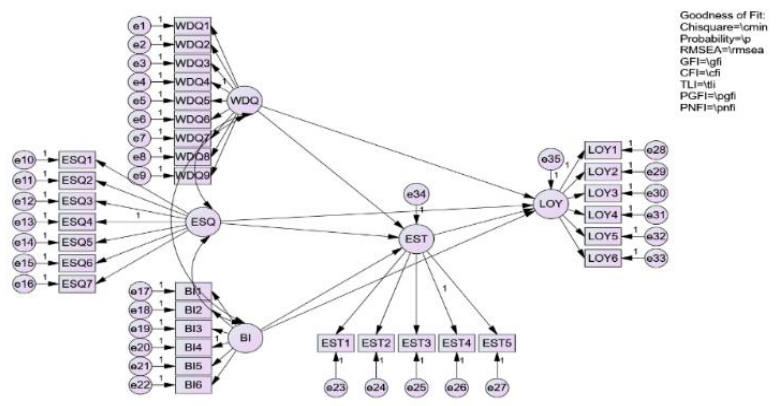

Figure 2. SEM Model

As we can see on the figure above, this step is to determine the model by connecting endogenous and exogenous latent constructs with indicator variables.

\section{Outlier Test}

The next stage is to see the presence of outliers. The results of the outlier test found 30 data that had outliers. Therefore, the 30 data must be deleted so that the data analyzed in the next process is 270 data.

Table 2. Mahalanobis Distance Test After Dropped Outliers

\begin{tabular}{|c|c|c|c|}
\hline Observation number & Mahalanobis d-squared & $\mathrm{p} 1$ & $\mathrm{p} 2$ \\
\hline 39 & 62,999 &, 001 &, 000 \\
\hline 110 & 62,407 &, 001 &, 000 \\
\hline 145 & 62,336 &, 002 &, 000 \\
\hline 91 & 62,271 &, 002 &, 000 \\
\hline 130 & 61,626 &, 002 &, 000 \\
\hline 113 & 61,018 &, 002 &, 000 \\
\hline 27 & 60,512 &, 002 &, 000 \\
\hline 75 & 60,149 &, 003 &, 000 \\
\hline
\end{tabular}




\begin{tabular}{|c|c|c|c|}
\hline 186 & 59,933 &, 003 &, 000 \\
\hline 13 & 59,732 &, 003 &, 000 \\
\hline 107 & 59,600 &, 003 &, 000 \\
\hline 51 & 59,551 &, 003 &, 000 \\
\hline 199 & 59,192 &, 003 &, 000 \\
\hline 218 & 59,118 &, 003 &, 000 \\
\hline 14 & 59,098 &, 003 &, 000 \\
\hline 173 & 59,014 &, 004 &, 000 \\
\hline
\end{tabular}

\begin{tabular}{|c|c|c|c|c|c|}
\hline ESQ3 & 0,776 & 0,602 & 0,398 & & \\
\hline ESQ2 & 0,684 & 0,468 & 0,532 & & \\
\hline ESQ1 & 0,677 & 0,458 & 0,542 & & \\
\hline BI5 & 0,77 & 0,593 & 0,407 & \multirow{6}{*}{0,9} & \multirow{6}{*}{0,6} \\
\hline BI6 & 0,83 & 0,689 & 0,311 & & \\
\hline BI4 & 0,8 & 0,640 & 0,360 & & \\
\hline BI3 & 0,723 & 0,523 & 0,477 & & \\
\hline BI2 & 0,796 & 0,634 & 0,366 & & \\
\hline BI1 & 0,751 & 0,564 & 0,436 & & \\
\hline EST5 & 0,791 & 0,626 & 0,374 & \multirow{5}{*}{0,9} & \multirow{5}{*}{0,6} \\
\hline EST4 & 0,797 & 0,635 & 0,365 & & \\
\hline EST3 & 0,828 & 0,686 & 0,314 & & \\
\hline EST2 & 0,711 & 0,506 & 0,494 & & \\
\hline EST1 & 0,757 & 0,573 & 0,427 & & \\
\hline LOY1 & 0,675 & 0,456 & 0,544 & \multirow{6}{*}{0,9} & \multirow{6}{*}{0,6} \\
\hline LOY2 & 0,746 & 0,557 & 0,443 & & \\
\hline LOY3 & 0,774 & 0,599 & 0,401 & & \\
\hline LOY4 & 0,846 & 0,716 & 0,284 & & \\
\hline LOY5 & 0,824 & 0,679 & 0,321 & & \\
\hline LOY6 & 0,809 & 0,654 & 0,346 & & \\
\hline
\end{tabular}

In the table above, it can be seen that the highest value of Mahalanobis d Square is 62.999 , below c-square value of 63.01. From these results, it can be concluded that there are no outliers in the data.

\section{Normality Data}

The assumption of data normality must be met so that the data can be processed for SEM modelling. Normality testing is done by observing the value of Critical Ratio (CR) data, if the value of CR multivariate data is between the range of \pm 2.58 , then the data can be normal.

The results of the data normality test showed that the multivariate CR value was 49,914 which was still above 2.58 . This result showed that the data is not normally distributed. To overcome normality in SEM, Ghozali (2008) suggested the bootstrap method through AMOS software. The bootstrap method is resampling-based. In this study, resampling was carried out 500 times with a bias-corrected confidence interval of $90 \%$. The results of the skewness calculation show that the skewness number is less than \pm 2.58 , thus the data meets the normal requirements.

\section{Validity and Reliability}

The following table is the result of testing the validity and reliability:

Table 3. Validity And Reliability Test

\begin{tabular}{|c|c|c|c|c|c|}
\hline & $\begin{array}{l}\text { Standar } \\
\text { Loading }\end{array}$ & $\begin{array}{c}\text { Standar } \\
\text { Loading }\end{array}$ & $\begin{array}{l}\text { Measurement } \\
\text { Error }\end{array}$ & CR & VE \\
\hline WDQ4 & 0,663 & 0,440 & 0,560 & \multirow{9}{*}{0,9} & \multirow{9}{*}{0,5} \\
\hline WDQ3 & 0,778 & 0,605 & 0,395 & & \\
\hline WDQ2 & 0,685 & 0,469 & 0,531 & & \\
\hline WDQ1 & 0,753 & 0,567 & 0,433 & & \\
\hline WDQ5 & 0,758 & 0,575 & 0,425 & & \\
\hline WDQ6 & 0,652 & 0,425 & 0,575 & & \\
\hline WDQ7 & 0,711 & 0,506 & 0,494 & & \\
\hline WDQ8 & 0,717 & 0,514 & 0,486 & & \\
\hline WDQ9 & 0,764 & 0,584 & 0,416 & & \\
\hline ESQ5 & 0,748 & 0,560 & 0,440 & \multirow{4}{*}{0,9} & \multirow{4}{*}{0,5} \\
\hline ESQ6 & 0,701 & 0,491 & 0,509 & & \\
\hline ESQ7 & 0,641 & 0,411 & 0,589 & & \\
\hline ESQ4 & 0,825 & 0,681 & 0,319 & & \\
\hline
\end{tabular}

From the table above, it can be seen that the construct reliability of all variables is more than 0.7 . While the variance extracted value for each variable is more than 0.5 . Hence, it can be concluded that the data used is reliable.

\section{Model Modification}

This model must be modified because several indicators have high modification index (MI). Modifications are done by providing a covariance relationship or eliminating indicators that have a high MI value.

Table 4. Goodness Of Fit Value After Modification

\begin{tabular}{|c|c|c|c|c|}
\hline Fit Index & $\begin{array}{c}\text { Goodness } \\
\text { of Fit }\end{array}$ & Criteria & $\begin{array}{c}\text { Cut-off } \\
\text { value }\end{array}$ & \\
\hline \multirow{4}{*}{ Absolute Fit } & Chisquare & Small & 277,211 & Fit \\
\cline { 2 - 5 } & Probability & $\geq 0.05$ & 0,031 & Marginal Fit \\
\cline { 2 - 5 } & RMSEA & $\leq 0.08$ & 0,026 & Fit \\
\cline { 2 - 5 } & GFI & $\geq 0.90$ & 0,931 & Fit \\
\hline $\begin{array}{c}\text { Incremental } \\
\text { Fit }\end{array}$ & CFI & $\geq 0.90$ & 0,991 & Fit \\
\cline { 2 - 5 } & TLI & $\geq 0.90$ & 0,988 & Fit \\
\hline $\begin{array}{c}\text { Parsimony } \\
\text { Fit }\end{array}$ & PGFI & $\geq 0.60$ & 0,656 & Fit \\
\cline { 2 - 5 } & PNFI & $\geq 0.60$ & 0,720 & Fit \\
\hline
\end{tabular}

\section{Hypothesis Testing}

The following table is the result of hypothesis testing using SEM. 
Table 5. Hypothesis Testing Result

\begin{tabular}{|c|c|c|c|c|c|c|c|}
\hline & & & Estimate & S.E. & C.R. & P & \\
\hline EST & $<-$ & WDQ &, 635 &, 144 & 4,419 & $* * *$ & Significant \\
\hline EST & $<-$ & ESQ &, 279 &, 081 & 3,427 & $* * *$ & Significant \\
\hline EST & $<-$ & BI &, 056 &, 104 &, 538 &, 591 & Not \\
\hline LOY & $<-$ & WDQ &,- 330 &, 266 & $-1,241$ &, 215 & Not \\
\hline LOY & $<-$ & ESQ &,- 230 &, 134 & $-1,723$ &, 085 & Not \\
\hline LOY & $<-$ & BI &, 515 &, 135 & 3,810 & $* * *$ & Significant \\
\hline LOY & $<-$ & EST & 1,015 &, 273 & 3,713 & $* * *$ & Significant \\
\hline
\end{tabular}

Website Design Quality has a positive and significant effect on the e-satisfaction of E-commerce customers. The estimation value is 0.635 , the t-statistic value is above 1.96 , which is 4.419 and the P-Value value is below 0.05 , which is 0.000 . So that the first hypothesis is supported.

E-service quality has a positive and significant effect on the e-satisfaction of e-commerce customers. The estimation value is 0.279 , the t-statistic value is above 1.96 , which is 3.427 and the p-value value is below 0.05 , which is 0.000 . Therefore, the second hypothesis is accepted.

Brand image has no significant effect on e-commerce customer e-satisfaction. The estimation value is 0.056 , the $\mathrm{t}$ statistic value is below 1.96, which is 0.538 and the P-Value value is above 0.05 , which is 0.591 . Thus, the third hypothesis is not supported.

Website design quality has no significant effect on the eloyalty of e-commerce customers. The estimation value is 0.330 , the t-statistic value is below 1.96 , which is -1.241 and the p-value is above 0.05 , which is 0.215 . Therefore, the fourth hypothesis is not supported.

E-service quality does not have a significant effect on the e-loyalty of e-commerce customers. The estimation value is -0.230 , the t-statistic value is below 1.96 , which is -1.723 and the p-value is above 0.05, which is 0.085. Thus, hypothesis 5 is not accepted.

Brand image has a positive and significant influence on the e-loyalty of e-commerce customers. The estimation value is 0.515 , the t-statistic value is above 1.96 , which is 3.810 and the p-value is below 0.05 , which is 0.000 . So that hypothesis 6 is supported.

E-satisfaction of e-commerce customers has a positive and significant effect on the e-loyalty of e-commerce customers. The estimation value is 1.015 , the t-statistic value is above 1.96, which is 3.713 and the P-Value value is below 0.05 , which is 0.000 . So that hypothesis 7 is supported.

\subsection{Discussion}

This study analysed 5 variables related to transactions in e-commerce, namely website design quality (WDQ), e-service quality (ESQ), brand image (BI), e-satisfaction (EST) and e- loyalty (LOY). This research model is built based on theory and previous research and is divided into 7 hypotheses.

Website design quality has a positive and significant influence on the e-satisfaction of e-commerce customers. This result is supported by several previous researchers such as Bernardo et al (2019) and Indriyani (2018). This study found a positive influence of website design quality on customer satisfaction. Thus, e-commerce platform managers should pay attention to the website design quality because it can affect customer satisfaction.

E-service quality has a positive and significant impact on e-commerce customer e-satisfaction. Research by Permana et al (2018) showed that there is a significant influence of each dimension of e-service quality, namely efficiency, system availability, fulfilment, privacy, responsiveness, compensation, and contact simultaneously on Shopee customer satisfaction in Bandung. The e-commerce company needs to pay attention and improve e-commerce e-service quality. The better the service quality, the better consumer satisfaction toward e-commerce platforms.

Brand image has no significant effect on e-commerce customer e-satisfaction. This result is in line with research by Mulyono (2016) which found that brand image does not affect e-satisfaction. This result is also in line with research from Kurniawan \& Hidayanti (2019) which also found that brand image does not significantly affect consumer satisfaction for Grab in Palembang. This study teaches us that a good brand image is not the main parameter of e-commerce customer satisfaction in Indonesia.

Website design quality has no significant effect on eloyalty of e-commerce customers. This result is in line with research by Abou-Shouk and Khalifa (2017) which found that design quality and interactivity did not affect consumer loyalty. This negative effect is because consumers are more concerned with the ease of use than the quality of design. Research by Pahlopi \& Arifin (2017) also found that website quality does not affect olx.com customer loyalty. This study showed that the quality of a good website design does not make e-commerce customers loyal. Some consumers prefer the ease of using a website rather than a good website design.

E-service quality does not have a significant effect on eloyalty of e-commerce customers. This result is in line with research by Romadhan et al (2019) which found that the eservice quality has no significant effect on Lazada consumer loyalty. However, this finding contradicts Laurent (2016) which found that e-service quality has an influence on GOJEK consumer loyalty.

This study showed that there is no difference between customer expectations of the performance of the electronic services before using the service and their perception of the service received. This means that good service quality cannot affect the loyalty of Indonesian e-commerce consumers. 
Brand image has a positive and significant influence on e-loyalty of e-commerce customers. This result is supported by the study by Wijayanto (2013) which found that brand image which consists of the strength of brand association, the advantages of brand association and the uniqueness of brand association partially has a significant influence on consumer loyalty. In addition, Pramudyo (2012) also found that there is a significant influence of brand image on loyalty. This study encourages e-commerce companies to maintain a good brand image because it has a significant impact on customer satisfaction.

E-satisfaction has a positive and significant effect on eloyalty of e-commerce customers. This result is in line with the research by Akhter et al. (2011) and Lin and Sun (2009) which found that customer loyalty is directly and positively influenced by customer satisfaction. These results show the importance of a company to maintain customer satisfaction when transacting on e-commerce platforms. Satisfaction can increase the loyalty of Indonesian e-commerce consumers.

\section{CONCLUSIONS}

This study aims to analyze the variables that affect the satisfaction and loyalty of e-commerce customers. The result showed, of the 7 hypotheses analysed, it was concluded that hypotheses 1, 2, 6 and 7 were supported and the rest were rejected. Furthermore, this research found that e-satisfaction was influenced by website design quality and e-service quality. While e-loyalty was influenced by brand image and esatisfaction. This research did not find any influence by brand image toward e-satisfaction.

For e-commerce companies, this research can be used as one of the considerations and sources of information for evaluation purposes. E-commerce companies should concern on website design, electronic service and brand image to increase customer satisfaction. Meanwhile, website design quality and e-service quality have no significant effect on customer loyalty. E-commerce companies can pay greater attention to indicators with low percentage values and then make improvements in the future.

\section{REFERENCES}

[1]. Abou-Shouk, M. A. (2017). The Influence Of Website Quality Dimensions On E-Purchasing Behaviour And E-Loyalty: A Comparative Study Of Egyptian Travel Agents And Hotels. Journal Of Travel \& Tourism Marketing, 34(5), 608-623.

[2]. Anderson, R. D. (2003). E-Satisfaction and E-Loyalty: A Contingency Framework. Psychology And Marketing, 20, Hal. 123-138.

[3]. Bernarto, I., Wilson, N., \& Suryawan, I. N. (2019). Pengaruh Website Design Quality, Service Quality, Trust dan Satisfaction terhadap Repurchase Intention (Studi Kasus: Tokopedia.Com). Jurnal Manajemen Indonesia, 19

[4]. Fahmi, M. (2018). Peran Kepercayaan Pelanggan dalam Memediasi Pengaruh Kualitas Website terhadap Loyalitas Pelanggan Online Shop. Jurnal Riset Sains Manajemen, 2.

[5]. Flavian, C. G. (2009). Web Design: A Key Factor for The Website Success. Journal Of Systems And Information Technology, 11(2), 168-184.
[6]. Indriyani, F. (2018). Analisis Pengaruh Kualitas Website , Kepercayaan, Promosi dan Harga terhadap Kepuasan Pelanggan Tokopedia. Jurnal Riset Manajemen, 5.

[7]. Kotler, P. (2002). Manajemen Pemasaran Jilid V Edisi Milenium. Jakarta: Pt. Prebalindo.

[8]. Kotler, P. A. (2008). Prinsip-Prinsip Pemasaran Jilid I. Jakarta: Erlangga.

[9]. Kotler, P., \& Keller. (2007). Manajemen Pemasaran Jilid I Edisi ke dua belas. Jakarta: PT. Indeks.

[10]. Kurniawan, M., \& Hildayanti, S. K. (2019). Analisis Merek, Harga, Pelayanan dan Promosi terhadap Kepuasan Konsumen Kota Palembang (Studi Kasus Konsumen Grab). Jurnal Ecoment Global, 4.

[11]. Laurent, F. (2016). Pengaruh E-Service Quality terhadap Loyalitas Pelanggan Go-Jek melalui Kepuasan Pelanggan. Agora, 4.

[12]. Laurent, F. (2016). Pengaruh E-Service Quality terhadap Loyalitas Pelanggan Go-Jek Melalui Kepuasan Pelanggan. Agora, 4.

[13]. Lin, C. (. (2010). In Search Of E-Service Value: TechnologyExploitation Vs Certainty-Seeking Online Behaviours. The Service Industries Journal, 30.

[14]. Lin, G. T., \& Sun, C.-C. (2009). Other Article Factors Influencing Satisfaction and Loyalty in Online Shopping: An Integrated Model. Emerald, 33.

[15]. Malik, M. E. (2012). Impact Of Brand Image, Service Quality and Price on Customer Satisfaction in Pakistan Telecommunication Sector. Nternational Journal Of Business And Social Science, 3 (23), $123-129$.

[16]. Mulyono, H. (2016). Brand Awareness and Brand Image Of Decision Making on University. Brand Awareness and Brand Image of Decision Making on University, 18(2), 163-173. 18(2), 163-173.

[17]. Oliver, R. (1980). A Cognitive Model Of The Antecedents and Consequences of Satisfaction Decisions. Journal Of Marketing Research, , 17(4), 460-469.

[18]. Oliver, R. (1997). Satisfaction: A Behavioral Perspective on The Consumer. New York, : Ny: Mcgraw.

[19]. Pahlopi, G. S., \& Arifin, R. (2017). Pengaruh Reputasi Perusahaan, Trust dan Website Quality terhadap Loyalitas Pelanggan Online Shop Olx.Com Studi Kasus pada Mahasiswa Fakultas Ekonomi Angkatan Tahun 2015 Universitas Islam Malang. E-Jurnal Riset Manajemen.

[20]. Parasuraman, A. \&. (2000). The Impact of Technology on The Qualityvalue-Value-Loyalty Chain: A Research Agenda. Journal of Academy Of Marketing Science, 28(1),, 168-174.

[21]. Parasuraman, A. Z. (2005). "E-S-Qual: A Multiple-Item Scale for Assessing Electronic Service Quality. Journal Of Series Research, 7, Vol. 7 No. 3, Pp. 213-233.

[22]. Permana, H., \& Djatmiko, T. (2018). Analisis Pengaruh Kualitas Layanan Elektronik (E-Service Quality) terhadap Kepuasan Pelanggan Shopee di Bandung. Sosiohumanitas, $X x$.

[23]. Perwira, B. T., Yulianto, E., \& Kumadji, S. (2016). Pengaruh EService Quality dan Perceived Value terhadap Kepuasaan Pelanggan dan Loyalitas Pelanggan (Survei Pada Mahasiswa S1 Universitas Brawijaya yang Melakukan Transaksi Pembelian Online dengan Mobile Application Tokopedia). Jurnal Administrasi Bisnis (Jab), 38.

[24]. Pramudyo, A. (2012). Pengaruh Citra Merek terhadap Loyalitas melalui Kepuasan Sebagai Intervening (Studi Pada Mahasiswa Perguruan Tinggi Swasta Di Yogyakarta). Jbma, 1.

[25]. Prasetyo, H. D., \& Purbawati, D. L. (2017). Pengaruh E-Service Quality dan E-Security Seals terhadap E-Satisfaction melalui Keputusan Pembelian Konsumen E-Commerce (Studi Kasus pada Konsumen Lazada Indonesia). Jurnal Ilmu Administrasi Bisnis.

[26]. Romadhan, R., Indriastuty, N., \& Prihandoyo, C. (2019). EService Quality Kepuasan Konsumen melalui E-Commerce terhadap Loyalitas Konsumen. Jurnal Geoekonomi, 10.

[27]. Romadhan, R., Indriastuty, N., \& Prihandoyo, C. (2019). EService Quality Kepuasan Konsumen Melalui E-Commerce terhadap Loyalitas Konsumen. Jurnal Geoekonomi, 10.

[28]. Santika, I. W., \& Pramudana, K. A. (2018). Peran Mediasi ESatisfaction pada Pengaruh E-Service Quality terhadap E-Loyalty 
Situs Online Travel Di Bali. Jurnal Inovasi Bisnis Dan Manajemen Indonesia, $I$.

[29]. Setiadi, N. J. (2003). Perilaku Konsumen: Konsep Dan Implikasi Untuk Strategi Dan Penelitian Pemasaran. Jakarta: Prenada Media.

[30]. Shankar, V. S. (2003). Customer Satisfaction And Loyalty In Online And Offline Enviroment. International Journal Of Research In Marketing, 20.

[31]. Sutabri, T. (2012). Analisis Sistem Informasi. Yogyakarta: Andi Offset.

[32]. Tobagus, A. (2018). Pengaruh E-Service Quality Terhadap ESatisfaction Pada Pengguna Di Situs Tokopedia. Agora, 6.

[33]. Wong, J. (2010). Internet Marketing For Beginners. Jakarta: Pt Elex Media Komputindo.
[34]. Yeridha, R. A., Kuleh, Y., \& Sampeliling, A. (2019). Pengaruh Persepsi Nilai Pelanggan Dan Brand Image Terhadap Loyalitas Pelanggan Jasa Ojek Online Go-Jek Di Samarinda. Jurna Manajemen, 11, 96-101.

[35]. Wijayanto, I. (2013). Pengaruh Citra Merek Terhadap Loyalitas Konsumen. Jurnal Ilmu Manajemen, 1.

[36]. Puspitasari, A. N., Kumadji, S., \& Sunarti. (2013). Pengaruh Kualitas Website Terhadap Nilai Yang Di Persepsikan Dan Loyalitas Pelanggan Online Shop (Studi Pada Tokoh Sepatu Wanita Www.Iwerup.Com). 5.

[37]. Yuhefizar. (2013). Cara Mudah \& Murah Membangun \& Mengelola Website. Yogyakarta: Graha ilmu. 